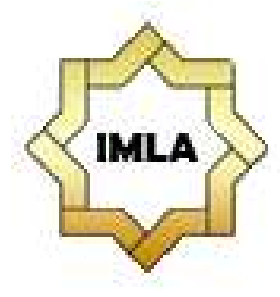

Al-Ta'rib

Jurnal Ilmiah Program Studi Pendidikan Bahasa Arab

IAIN Palangka Raya

Vol. 9, No. 2, December 2021, 205-214

p-ISSN 2354-5887 | e-ISSN 2655-5867

DOI: https://doi.org/10.23971/altarib.v9i2.2595

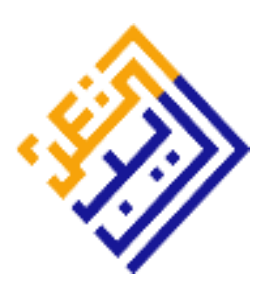

\title{
ESTAFET WRITING METHOD TO IMPROVE ARABIC WRITING SKILLS OUTCOMES: EXPERIMENTAL STUDY ON INDONESIAN MIDDLE SCHOOL STUDENTS
}

\author{
Nur Laila Sa'idah', Sholikah Mi'rotin ${ }^{2}$, Fentin Ria Agustin ${ }^{3}$ \\ 1,2,3Universitas Islam Negeri Maulana Malik Ibrahim Malang, Indonesia \\ Email: nurlailasaidah1991@gmail.com
}

\begin{abstract}
One of the language skills that require a process of practicing, learning, and proper techniques for teaching students in writing. By intensive practicing and studying, students become skillful faster. It seems difficult for students to compile their writing without making careful planning before writing. Many students cannot express their opinion because the teacher does not teach them properly. Teaching writing with monotone techniques inhibits students to get the ideas provided by the teacher during the writing learning process. This research focused on the methods used by the teacher in Maharah Kitabah (writing skills), which was at relay writing method (chain writing). The research method used was experimental, that data was collected by observation and test. Then, the data were analyzed by using the N-Gain. From the results of the N-Gain test, the average score of the pre-test and post-test scores has increased by a percentage of $59 \%$. While the average score obtained from the acquisition of the $\mathrm{N}$-gain value is 0.72 , therefore, the category was high. This result proves that the estafet writing method can improve Arabic writing skills outcomes.
\end{abstract}

Keywords: Estafet Writing, Active Learning, Writing Skill, Arabic Learning

Abstrak

Menulis merupakan salah satu ketrampilan bahasa yang membutuhkan proses berlatih, belajar, serta teknik yang tepat untuk mengajar siswa. Dengan sering berlatih dan belajar, maka siswa semakin cepat terampil. Tampaknya sulit bagi siswa untuk menyusun tulisannya tanpa membuat perencanaan yang matang sebelum menulis. Banyak siswa tidak dapat mengungkapkan pendapatnya karena guru tidak mengajar mereka dengan benar. Pengajaran menulis secara monoton menjadi masalah bagi siswa untuk mendapatkan informasi yang diberikan oleh guru selama pembelajaran menulis. Penelitian ini berfokus pada teknik yang digunakan guru dalam maharah kitabah (kemahiran menulis), yakni metode estafet writing (menulis berantai). Adapun metode penelitian ini adalah metode eksperimen dengan mengumpulkan data melalui observasi dan tes. Kemudian data tersebut dianalisis dengan uji $N$-Gain. Dari hasil uji $N$ - 
Gain, rata-rata dari hasil skor nilai pre-test dan post-test mengalami peningkatan dengan prosentase sebesar $59 \%$. Sedangkan rata-rata yang didapat dari hasil nilai $n$-gain adalah 0,72 sehingga kategorinya adalah tinggi. Hasil ini membuktikan bahwa metode estafet writing dapat meningkatkan hasil keterampilan menulis bahasa Arab.

Kata kunci: Estafet Writing, Active Learning, Maharah Kitabah, Pembelajaran bahasa Arab

\section{INTRODUCTION}

Writing is an activity that is hated by some people. They are used to communicating verbally with other people based on their experiences and events around them. So they have a little difficulty in doing writing activities that require them to read a lot as knowledge input for their material in writing. Apart from speaking, one of the means of communication is writing. However, the language used in writing is different from the language in speaking. The language used in oral communication is language as a tool for interaction and transactions, while the language used in writing must be structured, ideas are written systematically, and conveyed explicitly (Lahir, 2017). Writing has a purpose for communication, presents something (Hulpa dkk., 2016), give direction, explain certain things, convince someone, and summarize (Susanti, 2013). For writing to be understood its purpose, then writing requires that it must be clear and follow what is expected by the reader. Thus, a writer demands to be able to present quality writing so that the message contained reaches the reader correctly.

Writing learning is not only centered on the ability of students to write Arabic letters correctly or correct the khath only (Mustofa \& Hamid, 2020), but they are also required to be able to develop their minds and think about them in written form (Hastang, 2019). Aspects that students need to have in kitabah learning is able to write letters and understand spelling, and can express thoughts and feelings in written form (Wahyudin, 2020). In giving birth and developing thoughts in written form, adequate knowledge of grammar, vocabulary (Hamid, 2020) sentence structure is required (Setyorini \& Prastikawati, 2010). So having extensive knowledge allows the writer to move beyond the limitations of shortterm working memory (McCutchen, 2011), to produce understandable and quality writing. So writing is one of the skills that is considered difficult because writing requires two language skills at once, namely receptive skill and productive skill (Wijaya \& Pimada, 2019).

The problems that exist in the classroom when Arabic learning include, some students have difficulty in making sentences or composing in writing learning. The students prefer to talk to their friends rather than immediately doing the assignment. This is also caused by the lack of teacher mastery of learning materials, and lack of knowledge about methods, strategies, and learning media. The lecture method is the mainstay method used by teachers in learning activities, and student worksheets as a guide in learning to write. As a result, students are not motivated to learn. 
To create student motivation in improving the writing learning, a learning method is needed that can foster student activity in learning and can express their thoughts in written form during the writing learning activities. One of the offers of learning methods that are considered capable of increasing motivation in learning writing skill is the estafet writing method.

Estafet writing is a method of writing text that is carried out in a chain (Lahir, 2017). Each student writes one sentence of the predetermined text in turn, which at the end of the lesson will produce a complete text. The purpose of the estafet is to make students think that learning is fun and to give students space to express their thoughts on a particular topic. In addition, students will not feel bored because the learning activities are carried out in groups (Ansoriyah, 2018). The teacher's role is only as a facilitator (Sukiyanto, 2019), while students must be active in learning. Therefore, this method is part of the active learning approach (Saragih \& Rabbani, 2017), so it is predicted to increase students' ability to make an essay (Rahmawati, 2017).

Asri et al. (2020) said in their research, estafet writing is more effective in learning to write because the learning activities are carried out in groups to foster learning motivation in them. The estafet writing method can make changes to students when writing essays using German. They are very enthusiastic about participating in learning because the method is packaged in the form of games so that every student looks active in every learning activity. In addition, relay writing can also be applied in Indonesian (Darajat dkk., 2017). Fadlilah et al. (2020) also assume that students' writing skills can be improved through the estafet writing method. According to him, the estafet writing method can create a pleasant learning atmosphere so that students are motivated in learning to write and make them active in the learning process. Heriawan (2012) also added that the estafet writing method was able to stimulate students in building their imagination. Student learning outcomes are better when the teacher applies the estafet writing method because image media is a means of learning German writing skills (Katharina Moi S, 2018).

The previous research above shows that the estafet writing method is appropriate to be applied in kitabah learning which can improve learning outcomes or student motivation. However, previous studies were mostly used for writing poetry, rhymes in Indonesian, English, and German. The researchers have not found any research on the use of the estafet writing method to make paragraphs in writing learning the book in Arabic subjects. So this paper intends to provide innovations for teachers to use the estafet writing method in writing learning

This paper assumes that using the estafet writing method can help Arabic teachers in overcoming the problems of writing learning in class. Besides, learning to write in groups can help students express their imagination in making work in the form of writing, the learning atmosphere becomes more colorful, interesting, and shapes students' minds to be more creative. So that this writing estafet method can raise students' interest and motivation for students in writing learning. 


\section{METHOD}

In this study, the authors used the experimental method. According to Emmorey, experimentation is a type of research that is specifically used to determine which variables and how the relationship between these variables is formed (Emmorey, 2014). Besides, Alzabin (in Hula, 2020) states that this method has several advantages, namely: 1) it is easier to apply, 2) it can be done in real situations, and 3) the results are following the problems experienced by the teachers. The participants in this study were seventh-grade students in the 2020/2021 academic year at Madrasah Tsanawiyah Al-Ma'arif 02 Singosari Malang Regency with a total of 29 students. This participant is the result of sampling with the saturated sample technique because the number of students in class VII is only 29. As said by Sugiyono (2013) that, if the total population is less than one hundred, then all members of the population are used as samples.

The research design that was applied was a Pre-Experimental Design with the type of one-group pretest-posttest (Sugiyono, 2013). The reason for using this form of design is because there is only one group in the research group. This group was given a pretest and posttest. The pretest is used to see the students' skills in learning the book before using the estafet writing, while the posttest is used to see the students' skills after using the estafet writing method in learning the book. The difference between the results of the posttest and pretest is considered as the effect of the experimental treatment.

Observation and tests as techniques used to collect data (Sukmadinata, 2013). Observation is used to obtain information about the problems experienced by students and teachers in writing learning, while the test is used to see the skills of students in kitabah learning. Data analysis uses gain-normalized analysis <g>, which is a tool that can provide an overview of increasing learning outcomes scores between before and after the application of treatment (Sundayana, 2014). Gain-normalized analysis $<\mathrm{g}>$ is used to determine the effectiveness of the estafet writing method in writing learning. The average gain-normalized $<$ g $>$ is calculated by the formula (Widayanti, 2016) :

$$
<g>=\frac{\text { posttest score }- \text { pretest score }}{\text { maximum score }- \text { pretest score }}
$$

Then the nominated $\mathrm{N}$-gain is interpreted according to Hake's criteria as shown in the following table:

Table 1.

\section{Normalized Gain Criteria}

\begin{tabular}{cc}
\hline Normalized Gain Range & Criteria \\
\hline$<\mathrm{g}><0,30$ & Low \\
$0,70><\mathrm{g}>\geq 0,30$ & Medium \\
$<\mathrm{g}>\geq 0,70$ & High \\
\hline
\end{tabular}




\section{RESULTS AND DISCUSSION}

The research was conducted from October to November 2020 at Madrasah Tsanawiyah with 29 students. The details of the research implementation schedule are presented in table 2 below:

Table 2.

Research Schedule

\begin{tabular}{ccc}
\hline Day/Date & Time & Activity \\
\hline October 22, 2020 & $07.00-08.45$ & Observation \\
October 29, 2020 & $07.00-08.30$ & Pretest and 1st Meeting \\
November 5, 2020 & $07.00-08.30$ & $2^{\text {nd }}$ meeting \\
November 12, 2020 & $07.00-08.30$ & $3^{\text {rd }}$ meeting and Posttest \\
\hline
\end{tabular}

The steps for applying the estafet writing method in writing learning include: (1) the teacher chooses a topic that will be developed into a paragraph by the students, in this case, the material used is material that has been conveyed to students, namely al-adawat al-madrasiyyah; (2) the teacher makes 6 groups with 4-5 students; (3) the teacher gives each student a time limit in writing sentences of approximately 1 minute; (4) the first student writes 1 or 2 sentences on a piece of paper. At the end of the sentence, students must record their name, to know the owner of the sentence that does not match the topic being discussed. Then the paper containing the sentence was handed over to the friend on the right; (5) the second student continues (continues) the sentence by writing a few more sentences. Don't forget writing his name after sentence; (6) the paper continues to be rotated until the last student; (7) when the chain writing activity is finished, the last student to write hands the paper book over to the student who wrote first; (8) the first student reads the entire paragraph that has been written by his friends and puts a cross on the sentences that are out of sync or not following the theme. Then the student who wrote the sentence was notified of his mistake, and asked to correct his writing; (9) each group makes an appropriate title; (10) each student represents a member of his group to read his work and stick it on the class wall magazine.

The following are the results of the pre-test and post-test values that will be analyzed to determine the normalized gain:

Table 3.

Normalized Gain Recapitulation

\begin{tabular}{ccccc}
\hline Number & PRE TEST & POST TEST & NORMALIZED GAIN & CATEGORY \\
\hline 1 & 50 & 86 & 0.72 & high \\
2 & 73 & 93 & 0.74 & high \\
3 & 69 & 90 & 0.68 & high \\
4 & 55 & 89 & 0.76 & high \\
5 & 58 & 88 & 0.71 & high \\
6 & 74 & 93 & 0.73 & high \\
7 & 71 & 93 & 0.76 & high
\end{tabular}




\begin{tabular}{ccccc}
8 & 57 & 88 & 0.72 & high \\
9 & 68 & 100 & 1.00 & high \\
10 & 74 & 93 & 0.73 & high \\
11 & 75 & 93 & 0.72 & high \\
12 & 59 & 80 & 0.51 & medium \\
13 & 60 & 90 & 0.75 & high \\
14 & 55 & 76 & 0.47 & medium \\
15 & 55 & 76 & 0.47 & medium \\
16 & 60 & 90 & 0.75 & high \\
17 & 70 & 92 & 0.73 & high \\
18 & 70 & 93 & 0.77 & high \\
19 & 70 & 92 & 0.73 & high \\
20 & 64 & 90 & 0.72 & high \\
21 & 75 & 95 & 0.80 & high \\
22 & 60 & 90 & 0.75 & high \\
23 & 75 & 94 & 0.76 & high \\
24 & 50 & 86 & 0.72 & high \\
25 & 68 & 91 & 0.72 & high \\
26 & 77 & 100 & 1.00 & high \\
27 & 69 & 93 & 0.77 & high \\
28 & 74 & 93 & 0.73 & medium \\
29 & 58 & 84 & 0.62 & \\
\hline Amount & 1893 & 2611 & 21.04 & \\
\hline Average & 65,2 & 90 & 0.725618454 & \\
\hline
\end{tabular}

To make it easier to read the results of the inclusion criteria for the n-gain score from table 3 above, the following bar chart image will be presented:

\section{Graph 1.}

Normalized Gain Bar Chart

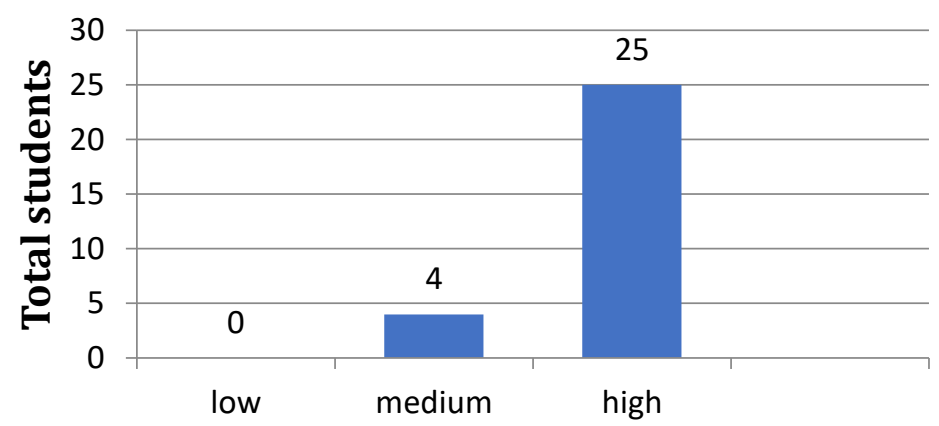

Based on the calculation of the n-gain value from the bar chart in graph 1 above, it shows that it is divided into two groups. A total of 4 students were in the medium category with a gain score of $0.70 \mathrm{~g}>0.30$, while 25 students were in the high category with a gain score of $1.0 \mathrm{~g}>0.70$. 
Based on the results of the pre-test and post-test, it can be seen from the assessment of student learning outcomes that have been presented in table 3. By looking at the table, it can be seen that the percentage of students' mastery in learning to write Arabic with the estafet writing method shows an increase. As many as 26 students did not reach the KKM in the descriptive writing task about the material of al-adawat al-madrasiyah. The KKM score determined by the school in Arabic lessons is 75. The score that does not reach a score of 75 is categorized as incomplete. The average pre-test score of students is 65 , so it can be said that the student's completeness score is $0 \%$, and this means that no student's score has achieved completeness in the Kitabah material about al-adawat al-madrasiyah. As for the post-test, the scores of all students have increased and have achieved the completeness of the KKM scores. The score of students' post-test scores has an average of 90 , so it can be said that the completeness of students' scores on the post-test is $100 \%$.

The results of the value of writing skills in this class have increased attainment. From table 3 it can be observed that the average pre-test and post-test scores have increased by a percentage of $59 \%$. While the average obtained from the results of the $n$-gain value is 0.72 so that the category is high. This shows that the estafet writing method is very efficient to be applied in writing learning.

This method is very helpful for students in expressing their ideas or ideas into written text. Because it is done in groups, each student is enough to make one sentence to produce a complete text. They become easier to develop their thinking. This is in line with the opinion of Sitti Syathariah (2011), that the purpose of the estafet is to make students think that learning is fun and to give students space to express their thoughts on certain topics. However, all of that cannot be separated from the guidance of the teacher and the skills of the teacher in overseeing the course of kitabah learning using the estafet writing method.

Several research results also prove that this method is effectively used in learning to write, especially in writing in the field of language. This effectiveness can be seen in the process of writing learning, and the results of the evaluation carried out after learning. In writing learning activities, the estafet writing method can make learning conditions more encouraging, so that students are more enthusiastic in implementing learning. This enthusiasm arises because this method is carried out in groups so that students will unconsciously become active and can socialize with their friends during the implementation of learning (Syathariah, 2011b). Activeness and enthusiasm in participating in learning because the method is packaged in the form of games, so that each student appears active in every activity (Asri dkk., 2020), so that it affects the results of student evaluations. The results of the writing evaluation carried out after students follow the writing estafet method will be much better and progress from the results of the previous evaluation. 


\section{CONCLUSION}

The use of the estafet writing method is very efficient for use in learning the book. Kitabah is the most difficult maharah because it is a skill that requires students to be able to express their thoughts in written form. By applying the estafet writing method in writing learning, student learning outcomes increase. This increase is evidenced by the results of research that has been carried out by researchers that the class that was given a test of the estafet writing method, the evaluation results increased by a percentage of 59 . While the average obtained from the acquisition of the n-gain value was 0.72 which had a high category.

This research implies that the esatafet writing method can help students improve the results of Arabic writing skills, but in the learning process, this cannot be separated from the guidance of the teacher. The teacher functions as a facilitator, namely who gives the direction of knowledge and appreciation so that the process of learning and teaching activities can be carried out according to expectations and well so that students can also write well and correctly.

\section{REFERENCE}

Ansoriyah, S. (2018). Pengaruh Metode Estafet Writing Menggunakan Media Audiovisal Terhadap Kemampuan Menulis Populer Mahasiswa. Pesona: Pekan Seminar Nasional Pendidikan Bahasa dan Sastra Indonesia, 1(1), 4854.

Asri, W. K., Dalle, A., \& Azizah, L. (2020). Penerapan Metode Estafet Writing dalam Keterampilan Menulis Karangan Berdasarkan Gambar Siswa SMA Negeri di Kabupaten Gowa. Seminar Nasional LP2M UNM, 935-940.

Darajat, T. L., Sunarya, D. T., \& Panjaitan, R. L. (2017). Penerapan Metode Estacoll (Estafet Writing And Collaborative Writing) untuk Meningkatkan Kemampuan Menulis Karangan. Jurnal Pena Ilmiah, 2(1), 1511-1520.

Emmorey, K. (2014). Iconicity as structure mapping. Philosophical Transactions of the Royal Society B: Biological Sciences, 369(1651), 20130301.

Fadlilah, H. N., Endang, U., \& Yuniartin, T. (2020). Peningkatan Kemampuan Menulis Siswa Melalui Menggunakan Metode Menulis Berantai (Estafet Writing). Bestari/ Jurnal Studi Pendidikan Islam, 16, 1907-1337.

Hamid, M. A. (2020). Mengukur Kemampuan Bahasa Arab: Untuk Studi Islam. UINMaliki Press.

Hastang, H. (2019). Upaya Optimalisasi Maharah Kitabah Melalui Model Pembelajaran Berbasis Proyek pada Materi al-Jumlah. Didaktika: Jurnal Kependidikan, 12(1), 62-75.

Heriawan, A. (2012). Metodologi Pembelajaran Kajian Teoritis Praktis Model, pendekatan, Strategi, Metode, dan Teknik Pembelajaran. Banten: LP3G (lembaga Pembinaan dan pengembangan Profesi Guru).

Hula, I. R. N. (2020). Peningkatan Kompetensi Kaidah Bahasa Arab bagi Pemula Menggunakan Al-Tadrībāt Al-Lughawīyah. Al-Ta'rib : Jurnal Ilmiah Program 
Studi Pendidikan Bahasa Arab IAIN Palangka Raya, 8(2), 213-228. https://doi.org/10.23971/altarib.v8i2.2054

Hulpa, W. N., Djuanda, D., \& Hanifah, N. (2016). Penerapan Metode ESCO (Estafet Writing and Collaborative Writing) dengan Media Gambar Untuk Meningkatkan Kemampuan Melengkapi Cerita Rumpang. Jurnal Pena Ilmiah, 1(1), 741-750. https://doi.org/10.23819/pi.v1i1.3564

Katharina Moi S, R. (2018). Keterampilan Menulis Paragraf Deskriptif Bahasa Jerman dengan Metode Estafet Writing Bermedia Gambar Siswa Kelas X SMAN 1 Gedangan. LATERNE, 7(1).

Lahir, S. (2017). Peningkatan Kemampuan Menulis Teks Recount Melalui Metode Estafet Writing Pada Siswa Kelas IX a SMP Negeri 6 Sukoharjo Semester I Tahun Pelajaran 2016/2017. Jurnal Ilmiah Edunomika, 1(02), 108-119.

McCutchen, D. (2011). From Novice to Expert: Language and Memory Processes in the Development of Writing Skill. Journal of Writing Research, 3(1), 51-68. https://doi.org/10.17239/jowr-2011.03.01.3

Mustofa, B., \& Hamid, M. A. (2020). Metode dan Strategi Pembelajaran Bahasa Arab. UIN-Maliki Press.

Rahmawati, N. (2017). Peningkatan Kemampuan Menulis Puisi Bebas Melaluil Penggunaan Metode Estafet Writing (Penelitian Tindakan Kelas pada Siswa Kelas VIII F SMP Negeri 1 Baregbeg). DIKSATRASIA, 1(2), 115-123.

Saragih, E. E., \& Rabbani, A. N. F. (2017). Teachers' Perceptions on Implementing Estafet WritingTechnique in Teaching Writing. English Journal, 20(2), 1323.

Setyorini, A., \& Prastikawati, E. F. (2010). Teaching Paragraph Writing Through Interactive and Process Approaches. Eternal, 1(2), 217979. https://doi.org/10.26877/eternal.v1i2.326

Sugiyono. (2013). Metode Penelitian Pendidikan Pendekatan Kuantitatif, Kualitatif, dan $R \& D$. Alfabeta.

Sukiyanto, S. (2019). Implementasi Model Pembelajaran Kooperatif Tipe Jigsaw dengan Menggunakan Pendekatan Active Learning pada Materi Bangun Datar. MUST: Journal of Mathematics Education, Science and Technology, $4(1), 57-76$.

Sukmadinata, N. S. (2013). Metode Penelitian Pendidikan. PT Remaja Rosdakarya.

Sundayana, R. (2014). Statistika penelitian pendidikan. Bandung: Alfabeta.

Susanti, A. (2013). Penggunaan Media Gambar Berseri untuk Meningkatkan Keterampilan Menulis Narasi Siswa Kelas IV SDN Tambak Kemeraan Kecamatan Krian. Jurnal Penelitian Pendidikan Guru Sekolah Dasar, 1(2), 111.

Syathariah, S. (2011a). Estafet writing (menulis berantai). Yogyakarta: LeutikaPrio. 
Syathariah, S. (2011b). Estafet Writing (Menulis Berantai). Leutika Prio.

Wahyudin, D. (2020). Metodologi Pembelajaran Bahasa Arab Berdasarkan Teori Unit dan Parsial. Remaja Rosda Karya.

Widayanti, A. N. D. (2016). Peningkatan Hasil Belajar Siswa melalui Pembelajaran Berbasis Pendekatan Saintifik pada Materi Kalor dan Perpindahannya pada Siswa Kelas VII. PENSA E-JURNAL: PENDIDIKAN SAINS, 4(03), 1-5.

Wijaya, I. S., \& Pimada, L. H. (2019). Ta'lim al-Imla'bi Al-Wasit al-Muta'addidah li Tarqiyyah Maharah al-Kitabah fi al-Lughah al-'Arabiyyah. Jurnal Al-Bayan: Jurnal Jurusan Pendidikan Bahasa Arab, 11(2), 320-339.

\section{COPYRIGHT NOTICE}

Authors retain copyright and grant the journal right of first publication with the work simultaneously licensed under a Creative Commons Attribution 4.0 International License that allows others to share the work with an acknowledgement of the work's authorship and initial publication in this journal. 